\title{
POJĘCIA I KONCEPCJE DOBROSTANU: PRZEGLĄD I PRÓBA UPORZĄDKOWANIA
}

DOMINIKA KARAŚ *

Instytut Psychologii, Uniwersytet Kardynała Stefana Wyszyńskiego w Warszawie

\section{STRESZCZENIE}

Głównym celem artykułu jest próba uporządkowania coraz większej liczby definicji dobrostanu i związanych z nim pojęć pokrewnych, przegląd terminologii i przedstawienie najpopularniejszych teorii. Artykuł obejmuje dwie główne części. W pierwszej omówione są najważniejsze konstrukty teoretyczne związane $\mathrm{z}$ dobrostanem i pokazane relacje między poszczególnymi terminami, gdyż przegląd literatury dotyczącej dobrostanu wskazuje, że często poszczególne definicje są niejasne, a terminologia nierzadko bywa mieszana czy wręcz mylona. Do omawianych pojęć należy nie tylko samo pojęcie dobrostanu, ale również takie terminy jak szczęście, zadowolenie z życia czy jakość życia. Celem artykułu jest pokazanie relacji między tymi pojęciami, a także elementów wspólnych i rozbieżnych między różnymi ujęciami teoretycznymi. W drugiej części zaprezentowane są wybrane współczesne koncepcje dobrostanu, m.in. cebulowa teoria szczęścia, koncepcje dobrostanu subiektywnego, trójwymiarowa koncepcja dobrostanu, koncepcja dobrostanu psychologicznego i ujęcia eudajmonistyczne.

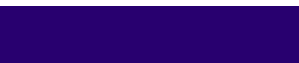

DOBROSTAN

JAKOŚĆ ŻYCIA

PSYCHOLOGIA POZYTYWNA

ROZKWIT

SZCZĘŚCIE

7 WPROWADZENIE

7 DOBROSTAN JAKO PRZEDMIOT ZAINTERESOWANIA PSYCHOLOGII POZYTYWNEJ

8 DOBROSTAN, JAKOŚĆ ŻYCIA ISZCZEŚCIE, CZYLI JEZZYK PSYCHOLOGII POZYTYWNEJ

15 WYBRANE WSPÓtCZESNE KONCEPCJE DOBROSTANU

21 PODSUMOWANIE

21 BIBLIOGRAFIA 


\title{
TERMS AND CONCEPTS OF WELL-BEING: REVIEW AND CLASSIFICATION ATTEMPT
}

\begin{abstract}
The main aim of the paper is an attempt to organize an increasing number of definitions of well-being and related concepts, to review the terminology and to present the most popular theories. The manuscript covers two main parts. In the first, the most important theoretical constructs related to well-being are discussed and the relationships between them are shown - as the review of the literature on well-being indicates that often some definitions are unclear, and terminology is often mixed or even confused. The discussed constructs include not only the concept of well-being, but also terms such as happiness, life satisfaction or quality of life. The aim of the article is to show the relationship between these concepts, as well as common and divergent elements between various theoretical approaches. The second part presents selected contemporary concepts of well-being, e.g. the onion theory of happiness, concepts of subjective well-being, three-dimensional concept of well-being, the concept of psychological well-being and eudaimonistic approaches.
\end{abstract}

\section{KEYWORDS}

well-being, quality of life, positive psychology, flourishing, happiness 


\section{WPROWADZENIE}

W

e współczesnej literaturze psychologicznej problematyka dobrostanu jest coraz bardziej popularna. Pojawiają się wciąż nowe koncepcje, narzędzia pomiarowe i wyniki badań nad różnymi aspektami dobrostanu (por. Compton, Hoffman, 2013; Lopez, Snyder, 2011; Seligman, 2011a). Celem niniejszego artykułu jest porządkujący przegląd terminologii oraz różnych ujęć teoretycznych związanych z tym złożonym zagadnieniem z zakresu psychologii pozytywnej.

Artykuł składa się z dwóch części: pierwsza $\mathrm{z}$ nich jest poświęcona przeglądowi pojęć stosowanych w koncepcjach dobrostanu, a druga - wybranym, najbardziej popularnym samym koncepcjom. W pierwszej części zostanie omówione w szczególności pojęcie szczęścia wraz z jego filozoficznymi korzeniami tkwiącymi w nurcie hedonistycznym i eudajmonistycznym. Zostanie również podjęta próba pokazania związków między pojęciami szczęścia i dobrostanu. Przedstawione zostanie także pojęcie jakości życia oraz jej elementów obiektywnych i pozytywnych, badanych w ramach różnych nurtów psychologii, a także pojęcia związane $z$ dobrostanem, takie jak prosperowanie/rozkwit, zdrowie psychiczne itp. Wreszcie zostanie podjęta próba uporządkowania najważniejszych współczesnych teorii według tego, czy w ich obszarze zainteresowania leży dobrostan hedonistyczny czy też eudajmonistyczny, w wymiarach subiektywnym lub obiektywnym. W części drugiej zostaną omówione przywołane teorie, do których należą: teoria subiektywnego dobrostanu Dienera (1984), teoria dobrostanu Seligmana (2011a), cebulowa teoria szczęścia Czapińskiego (1994), teoria szczęścia obiektywnego Kahnemana (1999), teoria dobrostanu subiektywnego Keyesa i Waterman (2003), teoria dobrostanu psychologicznego Ryff (1989), a także teoria dobrostanu eudajmonistycznego Watermana i in. (2010).

\section{DOBROSTAN JAKO PRZEDMIOT ZAINTERESOWANIA PSYCHOLOGII POZYTYWNEJ}

Termin well-being (dobrostan) pojawił się w definicji zdrowia sformułowanej w 1948 roku przez Światową Organizację Zdrowia (WHO). Definicja ta określała zdrowie jako „stan pełnego fizycznego, psychicznego i społecznego dobrostanu [well-being], a nie tylko brak choroby lub kalectwa" (WHO, 1948, s. 1). Jednak w owych czasach takie ujęcie nie pobudziło szerszych psychologicznych badań nad dobrostanem (Ryff, Singer, 2002). Dopiero kilkadziesiąt lat później narodziła się psychologia pozytywna, która zintensyfikowała zainteresowanie psychologii dobrostanem jako istotnym aspektem zdrowia i życia człowieka.

Określenia psychologia pozytywna prawdopodobnie po raz pierwszy użył w roku 1954 Abraham Maslow w książce Motivation and personality (Trzebińska, 2008). Maslow był jednym z najważniejszych przedstawicieli psychologii humanistycznej. Utożsamiał on zdrowie psychiczne $z$ samorealizacją i postulował takie uprawianie psychologii, aby mogła ona być wykorzystana w pomocy ludziom w osiąganiu zdrowia psychicznego. Dlatego też przedstawiciele psychologii humanistycznej traktują czasem psychologię pozytywną jako kontynuację tradycji maslowowskiej. Jednak jak pisze Trzebińska (2008), przedstawiciele psychologii pozytywnej zwracają uwagę na znaczące różnice między psychologią pozytywną a humanistyczną, związane przede wszystkim ze sposobem prowadzenia badań. 
W psychologii pozytywnej jest on oparty na precyzyjnej operacjonalizacji i pomiarze badanych zjawisk, zgodnie z metodologia głównego nurtu psychologii, co z kolei nie zawsze cechowało psychologię humanistyczną, sytuującą się w opozycji do głównego nurtu.

Formalne narodziny psychologii pozytywnej jako nowej dyscypliny naukowej datuje się zwykle na rok 1998 (Trzebińska, 2008). Wtedy to znany amerykański psycholog Martin Seligman wezwał członków Amerykańskiego Towarzystwa Psychologicznego do zmiany perspektywy współczesnej psychologii. Według niego powinna się ona zajmować bardziej wzmacnianiem ludzkiego potencjału niż naprawianiem ludzkich słabości. Zdaniem Seligmana (2002a) celem psychologii pozytywnej, oprócz poznawania człowieka, jest również oddziaływanie zmierzające do rozwoju jego potencjału oraz zwiększenie odczuwanego przez niego dobrostanu.

Obszarem zainteresowania psychologii pozytywnej jest szeroko pojęte dobre życie (Diener, Lucas, Oishi, 2002), obejmujące m.in.: dobrostan, satysfakcję z życia, radość, przyjemność, szczęście i konstruktywne schematy poznawcze. Przedstawiciele psychologii pozytywnej zwracają uwagę na to, że choć czasem człowiek doświadcza stresu, cierpienia i zaburzeń, to mimo wszystko jest istotą produktywną, cieszącą się życiem i twórczą (Seligman, 2002a). Psychologia pozytywna interesuje się wszystkimi zdrowymi i pożądanymi przejawami ludzkiego funkcjonowania, sposobem na ich wspieranie i wzmacnianie (Seligman, 2002a) oraz - jak twierdzi Maddux (2002) - pozwala na próbę zrozumienia, co sprawia, że ludzkie życie staje się wartościowe. Psychologia pozytywna, choć narodziła się stosunkowo niedawno, jest jedną z dynamicznie rozwijających się dziedzin psychologii, również polskiej, co znajduje wyraz w rosnącej liczbie badań, publikacji i konferencji z tej dziedziny (m.in.: Czerw, 2011, 2015; Kaczmarek, 2016; Kossakowska, 2014; Trzebińska, 2008; Zawadzka, Szabowska-Walaszczyk, 2014 i wiele innych).

Seligman (2002a) wskazuje na trzy główne sfery życia człowieka, których badaniem zajmuje się psychologia pozytywna. Pierwsza $z$ nich to sfera subiektywna, obejmująca pozytywne doświadczenia człowieka, dobrostan, zadowolenie z życia i doświadczanie przyjemności i szczęścia. Druga to sfera indywidualna. Ta odnosi się do pozytywnych właściwości człowieka, takich jak np. cnoty czy zdolności interpersonalne. Ostatnia sfera, nazywana grupową, obejmuje życie w społeczeństwie i takie wartości społeczne jak np. odpowiedzialność, altruizm czy tolerancja (Seligman, 2002a).

Ponieważ w literaturze można spotkać wiele pojęć związanych w różnym stopniu z zagadnieniem dobrostanu, warto uporządkować terminologię (rozróżniając takie pojęcia jak: dobrostan, jakość życia, szczęście) oraz naszkicować swoistą mapę teoretycznych ujęć dobrostanu. Próba taka zostanie podjęta w kolejnych częściach tego artykułu.

\section{DOBROSTAN, JAKOŚĆĊYCIA I SZCZĘŚCIE, CZYLI JĘZYK PSYCHOLOGII POZYTYWNEJ}

W literaturze zarówno polskiej, jak i anglojęzycznej można spotkać wiele terminów związanych $z$ dobrostanem. W niniejszym paragrafie postaramy się uporządkować nieco terminologię i język psychologii pozytywnej, wskazując na najważniejsze i najczęściej spotykane pojęcia oraz próbując wyjaśnić ich znaczenie.

\section{SZCZĘŚCIE, HEDONIZM I EUDAJMONIA}

Czapiński (1994) zauważa, że psychologia początkowo wykluczyła ze swojego obszaru badań konstrukty, które wiązały się z filozofią (takie jak np. wola życia, miłość czy szczęście), 
by nabrać charakteru bardziej empirycznego i obiektywnego. Jego zdaniem taki stan rzeczy sprawił, że psychologia przestała zajmować się sprawami najistotniejszymi dla każdego człowieka. Czapiński podkreśla też, że choć analiza takich konstruktów jak szczęście na gruncie psychologii nie dorównuje pod względem subtelności i głębi rozprawom filozofów, to jednak ma nad nimi przewagę empiryczną, dzięki wypracowanym przez psychologię metodom badań.

Pojęcie szczęścia zostało $\mathrm{w}$ pewnym sensie zrehabilitowane właśnie przez psychologię pozytywną i wprowadzone do języka głównego nurtu psychologii. Czapiński (1994) pisze, że termin dobrostan psychiczny w języku badań empirycznych używany jest jako synonim terminu szczęście. Zdaniem Dienera (2000) psychologię pozytywną można nawet nazwać nauką o szczęściu (happiness). Kahneman (1999) również uważa pojęcia szczęścia i dobrostanu za synonimy, a jeszcze do niedawna twórca psychologii pozytywnej, Seligman (2002b), pisał, że to właśnie szczęście jest głównym obszarem zainteresowania psychologii pozytywnej (w późniejszych publikacjach odróżnił jednak teorie szczęścia od teorii dobrostanu, co zostanie wyjaśnione w dalszej części).

Szczęście bywało jednak definiowane w filozofii różnie i różnie też jest rozumiane w psychologii. Współczesne teorie dobrostanu, wywodzące się z filozoficznych koncepcji szczęścia, nawiązują zwykle do dwóch tradycji: hedonistycznej, według której szczęście jest związane $\mathrm{z}$ odczuciem przyjemności i dążeniem do unikania nieprzyjemności, lub eudajmonistycznej, według której wiąże się ono z realizacją ludzkiego potencjału, poczuciem sensu i samorealizacji (Ryan, Deci, 2001).

Nurt badań nad dobrostanem hedonistycznym odwołuje się do filozoficznej koncepcji Arystypa z Cyreny. Przedstawiciele tego nurtu koncentrują się na badaniu doświadczania przyjemności (Ryan, Deci, 2001) i zaspokajania przez człowieka własnych potrzeb, doświadczania uczuć pozytywnych i satysfakcji z realizacji różnych celów życiowych (Czapiński, 2004). Zwykle nie analizują oni jednak, jakie są owe cele człowieka i w jaki sposób są realizowane (Czapiński, 2004). Pomiar dobrostanu hedonistycznego polega na zbadaniu subiektywnej oceny poziomu zadowolenia z życia (Trzebińska, 2008; por. Diener, 1984; Diener, Emmons, Larsen, Griffin, 1985; Kahneman, 1999). Jedną z najpopularniejszych teorii hedonistycznych jest koncepcja dobrostanu subiektywnego autorstwa Dienera (Diener, 1984; Diener, 2000; Diener i in., 1985) oraz koncepcja tzw. obiektywnego szczęścia Kahnemana (1999).

Nurt badań nad dobrostanem eudajmonistycznym nawiązuje z kolei do filozofii Arystotelesa, według którego szczęście jest realizacją cnoty, robieniem tego, co warte jest robienia (Ryan, Deci, 2001), życiem zgodnym z ludzką naturą (Waterman, 1993). Tradycja eudajmonistyczna odróżnia dobrostan od szczęścia subiektywnego (Ryan, Deci, 2001). Wskaźnikiem dobrostanu eudajmonistycznego nie jest odczuwane przez człowieka zadowolenie z życia, ale posiadanie przez niego pewnych wartościowych przymiotów, które sprawiają, że realizuje on swój potencjał (Trzebińska, 2008; por. Ryff, 1989). Do koncepcji eudajmonistycznych należą teoria dobrostanu psychologicznego Ryff (1989) oraz koncepcja dobrostanu Watermana i in. (2010). Zestawienie obu nurtów zostało przedstawione w tabeli 1.

Tabela 1. Porównanie eudajmonistycznego i hedonistycznego ujęcia dobrostanu

\begin{tabular}{lll}
\hline & Dobrostan hedonistyczny & Dobrostan eudajmonistyczny \\
\hline Przejawy: & Zadowolenie z życia & Działanie zgodne z ludzką naturą \\
& Odczucie przyjemności & Realizacja cnót \\
& Unikanie nieprzyjemności & Realizacja ludzkiego potencjału \\
& Subiektywne odczucie szczéścia & Poczucie celu i sensu \\
& Zaspokajanie własnych potrzeb & \\
\hline Przedstawiciele nurtu: & Diener, 1984; Kahneman, 1999 & Ryff, 1989; Waterman i in., 2010 \\
\hline & \multicolumn{2}{c}{ Ujęcia łączące oba nurty: } \\
& Czapiński, 1994; Keyes, Waterman, 2003 \\
\hline
\end{tabular}


Trzebińska (2008) podkreśla, że w badaniach psychologii tradycyjnej posługiwano się częściej ujęciem hedonistycznym, we współczesnej psychologii pozytywnej większego znaczenia nabrało natomiast ujęcie eudajmonistyczne. Czapiński (2004) wykazuje słabość zarówno podejścia hedonistycznego, w którym brakuje wskazania na źródło szczęścia, jak i eudajmonistycznego - ze względu na obecną w nim arbitralność definiowania dobrego życia i twierdzenie, że wszyscy mają taką samą naturę, a w konsekwencji - potrzeby. Wobec powyższych konkluzji Czapiński (2004) wskazuje na potrzebę integracji obu tych podejść. Do koncepcji, które łączą ujęcie hedonistyczne z eudajmonistycznym należą m.in.: cebulowa teoria szczęścia Czapińskiego (1994) oraz teoria dobrostanu subiektywnego Keyesa i Waterman (2003).

Czy szczęście to na pewno dobrostan? W psychologii pozytywnej zauważalna jest jednak również tendencja do definiowania dobrostanu w taki sposób, aby odróżnić go od pojęcia szczęścia. Odbywa się to zwykle przez wskazanie jakichś dodatkowych elementów, które znajdują się w definicji dobrostanu, ale nie ma ich w definicji szczęścia. Bradburn (1969) zauważył, że choć szczęście jest jednym z kryteriów pozytywnego zdrowia psychicznego (na co zwróciła uwagę Jahoda w 1958 roku), to jednak nie może być kryterium jedynym i wystarczającym, ponieważ zdarzają się stany, w których subiektywne odczucie szczęścia może być sygnałem zaburzeń psychicznych.

Według Ryff (1989) tłumaczenie arystotelesowskiej eudajmonii na język angielski jako happiness jest źródłem kłopotów terminologicznych i teoretycznych. Tłumaczenie takie może prowadzić do niwelacji istotnych różnic między dobrostanem rozumianym eudajmonistycznie i hedonistycznie. Ryff podkreśla, że szczęście związane z dobrostanem eudajmonistycznym jest uczuciem towarzyszącym realizacji ludzkiego potencjału, a nie subiektywnym doznaniem szczęścia, które jest celem ludzkiego życia w tradycji hedonistycznej.

Seligman (2011a,b) w swoich ostatnich publikacjach również odróżnia szczęście od dobrostanu. Rewiduje tym samym swój dotychczasowy pogląd, jakoby to szczęście było głównym obszarem zainteresowania psychologii pozytywnej. Seligman odróżnia teorie dobrostanu od teorii szczęścia. Uważa, że miarą szczęścia jest odczuwane zadowolenie z życia, wiążące się nieodłącznie z dobrym nastrojem i pozytywnymi emocjami. Dobrostan natomiast zdaniem Seligmana jest czymś innym niż szczęście. Jest konstruktem składającym się z wielu elementów (wśród nich są m.in.: pozytywne emocje, zaangażowanie, poczucie sensu i celu w życiu, pozytywne relacje i osiągnięcia). Seligman zaproponował zestaw kryteriów, które muszą być spełnione, aby dany element został zaliczony jako składowa dobrostanu. Każdy z owych elementów musi zatem: a) przyczyniać się do ogólnego dobrostanu, b) być realizowany dla siebie samego, a nie w celu osiągnięcia pozostałych elementów oraz c) być osobno zdefiniowany i mierzony.

Zdaniem Seligmana (2011a), jeśli przyjąć, że psychologia pozytywna będzie się koncentrować na szczęściu, to jej celem będzie wzrost zadowolenia z życia. Jeśli jednak owa gałąź psychologii skoncentruje się na dobrostanie, którego wymiarami są pozytywne emocje, zaangażowanie, poczucie sensu, pozytywne relacje $z$ innymi ludźmi i osiągnięcia, to jej celem będzie zwiększenie ludzkiego rozkwitu (flourishing). Pojęcie rozkwitu obejmuje rozwój potencjału człowieka we wszystkich obszarach jego funkcjonowania i zostanie omówione w dalszej części niniejszego artykułu. Seligmanowskie rozróżnienie między teorią szczęścia a dobrostanu zostało podsumowane w tabeli 2 . 
Tabela 2. Różnice między teorią szczęścia a teorią dobrostanu w ujęciu Seligmana (2011a)

\begin{tabular}{lll}
\hline & \multicolumn{1}{c}{ Teoria szczęścia } & \multicolumn{1}{c}{ Teoria dobrostanu } \\
\hline Przedmiot & Szczęście & Dobrostan \\
\hline Wskaźnik & Zadowolenie z życia & $\begin{array}{l}\text { Pozytywne emocje, zaangażowanie, poczucie sensu i celu } \\
\text { wżyciu, pozytywne relacje, osiągnięcia }\end{array}$ \\
\hline Cel praktyczny & Zwiększać zadowolenie z życia & $\begin{array}{l}\text { Zwiększać rozkwit przez zwiększanie pozytywnych emocji, } \\
\text { zaangażowania, poczucia sensu i celu w życiu, pozytywnych } \\
\end{array}$ \\
& relacji i osiągnięćc \\
\hline
\end{tabular}

Jak twierdzi Seligman (2011a), samo odczucie zadowolenia $\mathrm{z}$ życia nie powinno zajmować centralnego miejsca w żadnej nauce, która ma aspirację do bycia czymś więcej niż tylko „szczęściologią” ( happiology). Podkreśla również, że nie ma jednej miary dobrostanu, ponieważ przyczynia się do niego wiele elementów.

\section{JAKOŚĆ ŻYCIA}

W literaturze psychologicznej pojawia się często również termin jakośc życia (quality of life). Bywa on używany jako synonim dobrostanu (por. Heszen-Niejodek, 1996; Keyes, 1998; Waterman i in., 2010). Bywają też ujęcia jakości życia jako konstruktu różnego od dobrostanu (Forgeard, Jayawickreme, Kern, Seligman, 2011), a także jako kategorii szerszej, obejmującej m.in. dobrostan (por. Greene-Shortridge, Odle-Dusseau, 2009).

Trzebińska (2008) wskazuje różnice między tymi dwoma pojęciami, polegające na tym, że ocena jakości życia odnosi się nie tylko do subiektywnej oceny dokonywanej przez człowieka, ale również do czynników zewnętrznych, takich jak np. sytuacja mieszkaniowa i materialna, a nawet do czynników gospodarczych, jak poziom bezrobocia czy dostęp do opieki zdrowotnej. Dobrostan natomiast jest wymiarem bardziej subiektywnym, odnoszącym się do stanu psychicznego i właściwości psychicznych danego człowieka. Być może to właśnie dlatego termin dobrostan psychiczny $\mathrm{w}$ odniesieniu do angielskiego słowa well-being jest często w literaturze polskiej stosowany wymiennie z dobrostanem (por. Czapiński, 1994; Trzebińska, 2008; Wojciechowska, 2011).

Trzebińska (2008) podkreśla również, że pomiar jakości życia często sprowadzony jest do jednego współczynnika statystycznego (jak np. wskaźnik rozwoju społecznego - buman development index; HDI), co ogranicza użyteczność stosowania tego pojęcia $\mathrm{w}$ badaniach naukowych z zakresu psychologii. I choć pewne czynniki demograficzne mają związek $z$ dobrostanem, to jednak związek ten nie jest silny. Dlatego też warto utrzymać rozróżnienie między owymi dwoma pojęciami.

Rozróżnienie takie zostało poczynione m.in. przez Forgeard, Jayawickremego, Kern i Seligmana (2011), którzy podkreślają, że wskaźniki społeczno-ekonomiczne jakości życia stosowane od lat 60 . XX wieku przez socjologów (takie jak wskaźnik bezdomności, edukacji i wykształcenia, średnia długość życia) nie odzwierciedlają subiektywnego dobrostanu człowieka. Uważają oni również, że dobrostan ma wiele aspektów, a przyszłe badania empiryczne powinny skoncentrować się właśnie na jego wielowymiarowej naturze. Również Schwarz i Strack (1999) dowodzą, że relacja między obiektywnymi wydarzeniami z życia człowieka a subiektywnym dobrostanem jest słaba. Greene-Schortridge i Odle-Dusseau (2009) stwierdzają natomiast, iż pojęcie jakości życia jest pojęciem szerszym niż pojęcie dobrostanu i obejmuje zarówno wskaźniki obiektywne (jak zdrowie czy status materialny), jak i subiektywne (jak np. satysfakcja z różnych aspektów życia), dlatego też dobrostan jest elementem jakości życia, a nie pojęciem względem niej synonimicznym. 
Podsumowując powyższe ujęcia i rozważania, w artykule tym przyjęto rozumienie dobrostanu jako subiektywnego elementu jakości życia. Szerokie rozumienie jakości życia, uwzględniające elementy obiektywne i subiektywne, jest przedstawione na rysunku 1.

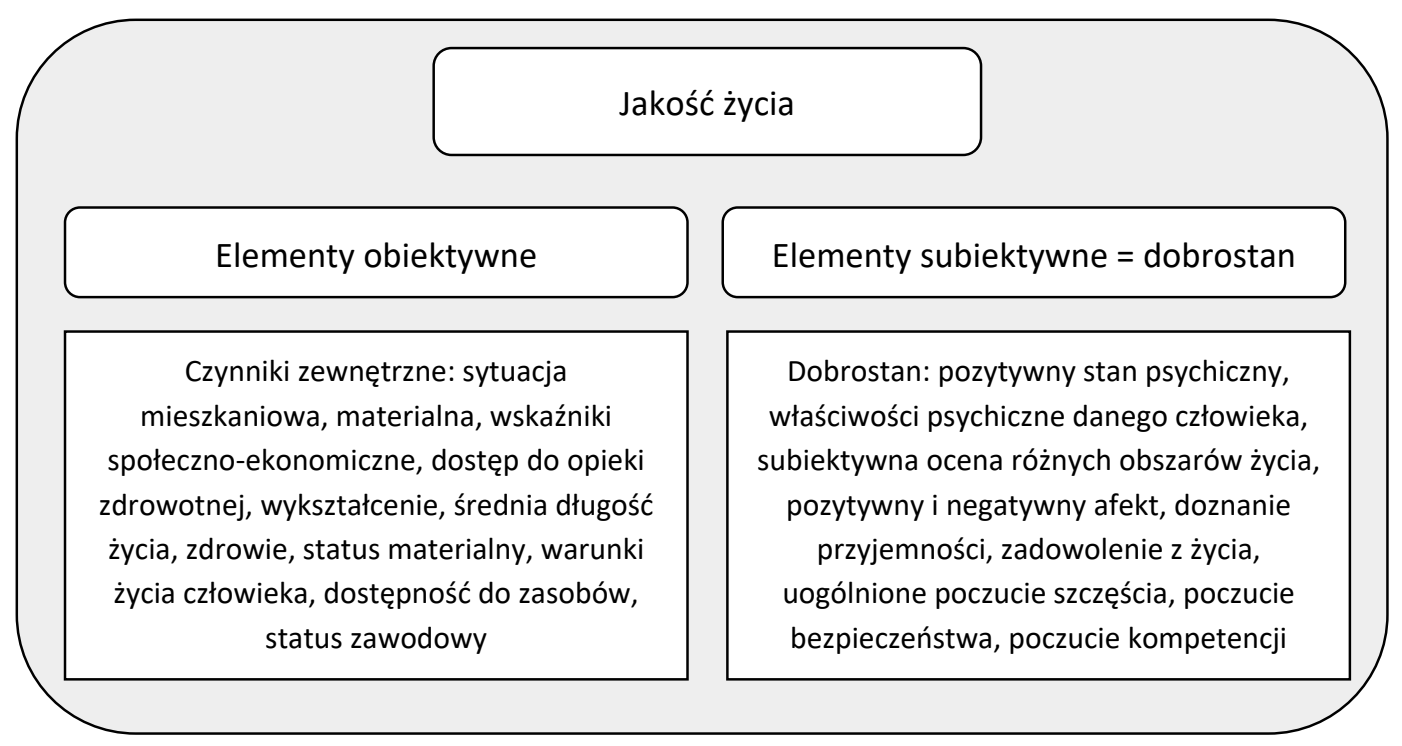

Rysunek 1. Jakość życia a dobrostan.

\section{DOBROSTAN SUBIEKTYWNY I OBIEKTYWNY}

W literaturze spotyka się również podział dobrostanu na subiektywny i obiektywny (Diener, 1984; Forgeard i in., 2011; Kahneman, 1999; Keyes, Waterman, 2003; Moore, Keyes, 2003; Schueller, Seligman, 2010; Schwarz, Strack, 1999; Seligman, 2011a; Waterman i in., 2010). Rozróżnienie to jest bliskie rozróżnieniu na jakość życia i dobrostan, ale nie jest z nim tożsame, dlatego też warto te dystynkcje omówić.

Moore i Keyes (2003) używają terminu dobrostan subiektywny (subjective well-being) na określenie tego, co w powyższym paragrafie jest wyrażone pod pojęciem dobrostanu, a terminu dobrostan używają w znaczeniu szerszym, zbliżonym do określenia jakość życia. Posługując się tymi pojęciami, dowodzą, że psychologia zaczęła interesować się wymiarami dobrostanu subiektywnego od czasów Jahody (1958), która zwróciła uwagę na elementy pozytywnego zdrowia psychicznego, i twierdzą, iż aby badać dobrostan, oprócz oceny obiektywnej jakości życia niezbędne jest zbadanie jej subiektywnej percepcji przez człowieka. W tym ujęciu - można by zatem powiedzieć - zbliżone jest znaczenie nie tyle poszczególnych pojęć (takich jak dobrostan czy jakość życia), ile par pojęć częściowo przeciwstawnych. Pierwszą parą jest dobrostan subiektywny vs dobrostan, a drugą - dobrostan vs jakość życia.

Używanie określenia subiektywny akcentuje podmiotowy aspekt dobrostanu. Na przykład Waterman i in. (2010) piszą, że koncepcje dobrostanu subiektywnego skupiają się na obecności i częstotliwości emocji pozytywnych, ich przewadze nad emocjami negatywnymi oraz ocenie ogólnej satysfakcji z życia (por. Diener, 2000). W tych koncepcjach zwykle nie ma rozróżnienia na źródła szczęścia eudajmonistyczne i hedonistyczne, ale badania empiryczne dotyczą przeważnie tylko hedonistycznego aspektu owego dobrostanu, jak wspomniana wyżej satysfakcja $z$ życia (Waterman $i$ in., 2010). 
$\mathrm{Na}$ marginesie warto dodać, że w rozumieniu eudajmonistycznym dobrostan może mieć aspekt zarówno subiektywny (poczucie realizacji własnego potencjału), jak i obiektywny (zachowania połączone $\mathrm{z}$ eudajmonistycznymi celami). Jak wskazują McMahan i Estes (2011), z perspektywy eudajmonistycznej dobrostan stanowi obiektywną konsekwencję życia zgodnego z ludzką naturą, z perspektywy hedonistycznej natomiast jest związany z subiektywnym pozytywnym stanem psychicznym (McMahan, Estes, 2011).

Rozróżnienie dobrostanu subiektywnego i obiektywnego dokonane przez Forgeard i in. (2011) bliskie jest rozróżnieniu na rozważaną wyżej parę pojęć dobrostanu i jakości życia. W ujęciu tych autorów składniki subiektywne to np.: poczucie szczęścia, zadowolenie z życia, doświadczanie pozytywnych emocji, poczucie celu i sensu, poczucie kompetencji, doświadczanie wsparcia społecznego. Podkreślają jednak trudności z wyznaczeniem miar obiektywnych (takich jak np. materialny poziom życia), które nie muszą odzwierciedlać poziomu wskaźników subiektywnych, jak i z wyznaczeniem ich obiektywnej i wyczerpującej listy. Główna różnica między podejściami subiektywnymi i obiektywnymi polega zdaniem wspomnianych autorów na tym, że podejścia subiektywne koncentrują się na stanach psychicznych, obiektywne zaś - nie. Jakość życia (mierzona wskaźnikami społecznymi) należy ich zdaniem do wymiarów obiektywnych. $Z$ kolei Diener (1984) zauważa, że takie wymiary jak zdrowie, komfort czy majątek mają charakter obiektywny i ich związek z dobrostanem subiektywnym jest niewielki. Potwierdzają to wyniki badań przedstawione przez Schwarza i Stracka (1999).

Do najpopularniejszych teorii dobrostanu subiektywnego należą: koncepcja Dienera (Diener, 1984, Diener, 2000; Diener i in., 1985), zaliczana do koncepcji hedonistycznych i uwzględniająca afektywne (częstotliwość doświadczania emocji pozytywnych) i poznawcze (zadowolenie z życia) komponenty dobrostanu, oraz wspomniana wcześniej teoria Keyesa i Waterman (2003), która obejmuje trzy wymiary dobrostanu subiektywnego: emocjonalny, psychologiczny i społeczny (pierwszy z nich ma charakter hedonistyczny, dwa pozostałe zaś obejmują funkcjonowanie człowieka w sferach psychologicznej i społecznej i mają charakter eudajmonistyczny).

Pojawiają się też jeszcze inne rozróżnienia dobrostanu subiektywnego i obiektywnego. Kahneman (1999), który - jak wspomniano wcześniej - stosuje pojęcia szczęścia i dobrostanu wymiennie, podkreśla, że dobrostan subiektywny jest odczuwaniem szczęścia w danym momencie życia, szczęście obiektywne zaś wynika z oceny jakości szeregu hedonistycznych doświadczeń życiowych. Gilman, Huebner i Buckman (2009) wyróżniają dwa rodzaje komponentów zadowolenia z życia (które jest jednym ze składników dobrostanu): obiektywne (m.in. wielkość dochodu, status zawodowy czy dostępność zasobów środowiska) i subiektywne (m.in. nastrój, cele, oczekiwania). Zdaniem Greene-Shortridge i Odle-Dusseau (2009) natomiast dobrostan subiektywny jest elementem jakości życia, która z kolei obejmuje również komponenty obiektywne.

Seligman (2011a), rewidując swoją teorię szczęścia i zmieniając ją na teorię dobrostanu, również zauważa, że dobrostan może mieć charakter obiektywny lub subiektywny. Wyróżnia on pięć mierzalnych elementów dobrostanu: pozytywne emocje (positive emotions), zaangażowanie (engagement), relacje $\mathrm{z}$ innymi ludźmi (relationships), poczucie sensu i celu $\mathrm{w}$ życiu (meaning and purpose) i osiągnięcia (accomplishment). Seligman uważa, że niektóre $\mathrm{z}$ tych elementów mogą być mierzone za pomocą subiektywnych skal samoopisu, a niektóre - jak relacje z innymi ludźmi czy osiągnięcia - również wskaźnikami obiektywnymi. Zdaniem Seligmana pomiar szczęścia (operacjonalizowanego jako zadowolenie $z$ życia) miał charakter wyłącznie subiektywny.

Podsumowując, nie można jednoznacznie powiedzieć, że podział na dobrostan subiektywny i obiektywny odzwierciedla podział na hedonię i eudajmonię lub podział na dobrostan i jakość życia. Dobrostan subiektywny może mieć zarówno komponenty hedonistyczne (por. Diener, 1984; Keyes, Waterman, 2003), jak i eudajmonistyczne (por. Keyes, Waterman, 
2003). Dobrostan obiektywny może być utożsamiany z eudajmonią (Trzebińska, 2008), ale może mieć też wymiar hedonistyczny (Kahneman, 1999), eudajmonia z kolei również może mieć wymiary subiektywny i obiektywny (Waterman i in., 2010). Dobrostan obiektywny może być rozumiany jako jakość życia (Schwarz, Strack, 1999), może też być jednak interpretowany zupełnie inaczej (por. hedonistyczna teoria szczęścia obiektywnego; Kahneman, 1999), a zarówno subiektywne zadowolenie z życia, jak i poczucie szczęścia mogą opierać się i na obiektywnych standardach, i na subiektywnych odczuciach (Gilman,Huebner,Buckman, 2009; Tatarkiewicz, 1985). Wydaje się, że wyznaczenie miar obiektywnych dobrostanu na gruncie psychologii może nastręczać pewnych trudności, ponieważ większość narzędzi opiera się na subiektywnym samoopisie (Forgeard i in., 2011), i odwrotnie: obiektywne wskaźniki społeczno-ekonomiczne nie muszą odzwierciedlać wskaźników subiektywnego dobrostanu.

Jak widać, granice między poszczególnymi rodzajami dobrostanu są płynne i zależne od orientacji teoretycznej - próbę przedstawienia tych złożonych powiązań prezentuje rysunek 2 .

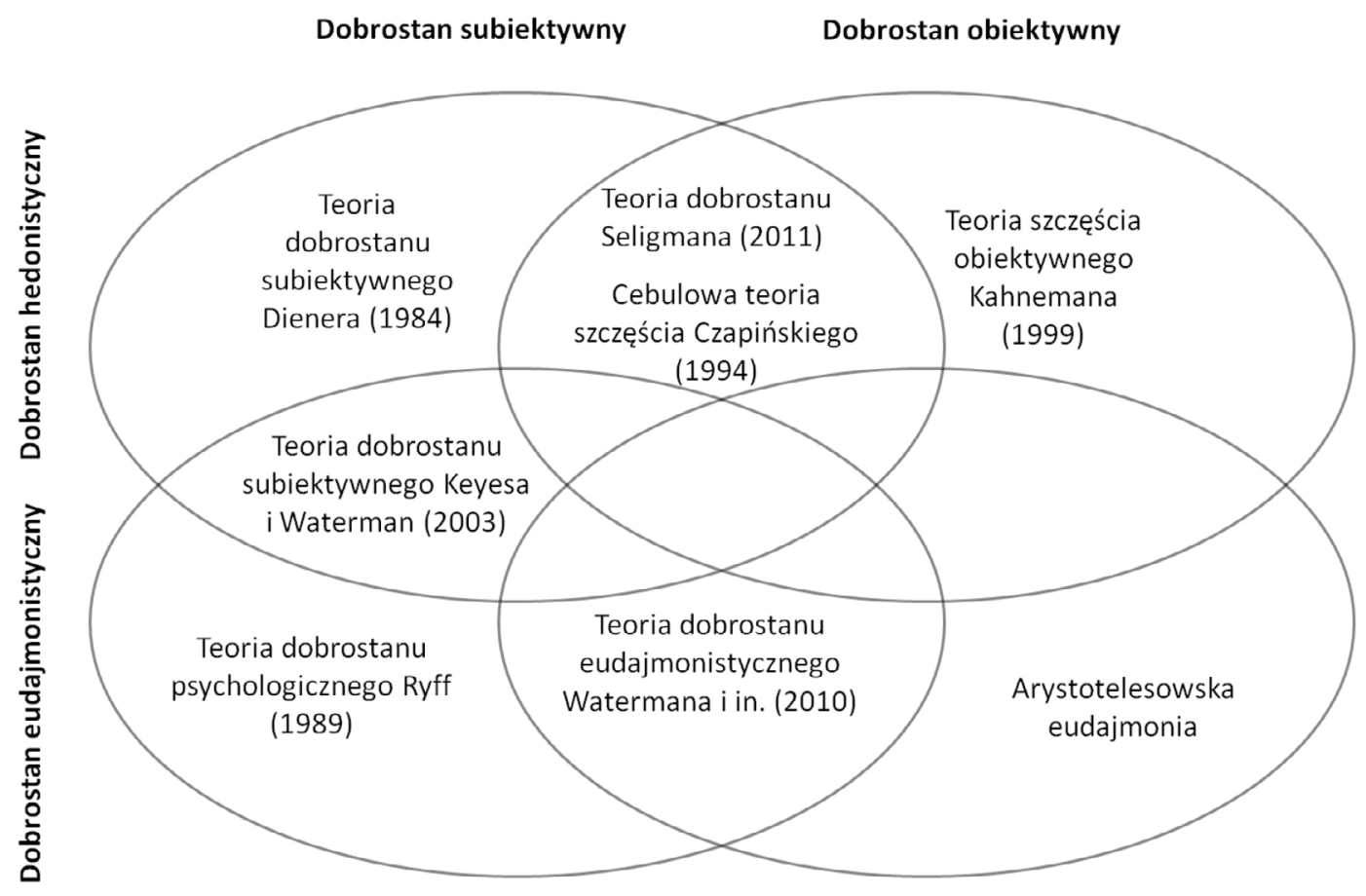

Rysunek 2. Klasyfikacje i teorie dobrostanu.

\section{PROSPEROWANIE/ROZKWIT}

Pojęciem stosowanym w literaturze $\mathrm{z}$ zakresu psychologii pozytywnej jest również angielski termin flourishing (por. Keyes, Lopez, 2002). Jako polski odpowiednik tego pojęcia Trzebińska (2008) proponuje określenie prosperowanie. Podkreśla zarazem, że słowo to wprawdzie nie należy jeszcze do języka polskiej psychologii, ale warto je do niego wprowadzić. Obecnie jednak w polskich przekładach częściej chyba spotyka się termin rozkwit (por. tłumaczenie książki Seligmana [2011b] oraz Gulla, Tucholska [2007]). Pojęcie to obejmuje dobry stan fizyczny, pozytywne relacje z innymi ludźmi i rozwój potencjału człowieka we wszystkich obszarach jego funkcjonowania. W odróżnieniu od pojęcia jakości życia pojęcie 
prosperowania/rozkwitu lub też dobrego funkcjonowania związane jest $\mathrm{z}$ aktywnością człowieka, a nie $\mathrm{z}$ warunkami, w jakich człowiek żyje (Trzebińska, 2008).

Zdaniem Seligmana (2011a) psychologia pozytywna powinna skupiać się na tym, by wzmacniać rozkwit człowieka przez wzmacnianie różnych wymiarów jego dobrostanu (który w koncepcji Seligmana jest w zasadzie utożsamiany z rozkwitem). Pojęcie szczęścia nie oddaje wg niego natury ludzkiego rozkwitu. Terminu rozkwit używa również Keyes (2002), który określa go jako kompletne zdrowie psychiczne (complete mental healtb), czyli stan charakteryzowany zarówno przez wysoki poziom dobrostanu, jak i niski poziom psychopatologii. Zdaniem Ryff i Singera (1998) jest to zmierzanie ku doskonałości, związane z realizacją ludzkiego potencjału. $Z$ kolei wg Fredrickson i Losady (2005) rozkrwitać znaczy: żyć w optymalnym zakresie funkcjonowania człowieka, który to zakres wiąże się z dobrocią, generatywnością, osobistym rozwojem i odpornością psychiczną.

\section{WYBRANE WSPÓKCZESNE KONCEPCJE DOBROSTANU}

Jak pokazano na rysunku 2, współcześnie powstają teorie, które łączą podejście eudajmonistyczne $z$ hedonistycznym, elementy subiektywne z obiektywnymi, pojęcie jakości życia $z$ dobrostanem oraz szczęściem. Poniżej przedstawimy i omówimy kilka najbardziej popularnych teorii dobrostanu.

\section{CEBULOWA TEORIA SZCZĘŚCIA CZAPIŃSKIEGO}

Cebulowa teoria szczęścia Czapińskiego (1994) należy do ujęć łączących podejścia hedonistyczne i eudajmonistyczne, zawiera w sobie również elementy obiektywne i subiektywne. Czapiński używa pojęć szczęścia i dobrostanu zamiennie. W jego teorii wyróżnione są trzy warstwy (zwane poziomami dobrostanu), podobnie do warstw cebuli (stąd oczywiście nazwa teorii). Pierwsza to wola życia (nie zawsze odczuwana subiektywnie), która może być uznana za obiektywny element dobrostanu człowieka. Kolejna warstwa to subiektywnie doświadczana wartość życia, zawierająca elementy hedonistyczne (takie jak satysfakcja z życia) oraz eudajmonistyczne (np. poczucie sensu życia). Trzecia zaś, najbardziej zewnętrzna, to bieżące doświadczenia afektywne oraz satysfakcje cząstkowe z poszczególnych sfer życia człowieka (elementy hedonistyczne). Czapiński podkreśla, że najbardziej podatne na bieżącą (obiektywną) sytuację życiową człowieka są elementy hedonistyczne, czyli satysfakcje cząstkowe, najmniej zaś - wola życia (która pełni funkcję tzw. atraktora szczęścia, polegającą na zapobieganiu obniżeniu się chęci życia oraz przywracaniu po negatywnych wydarzeniach poziomu szczęścia właściwego danej osobie). Czapiński zwraca również uwagę, że po negatywnych wydarzeniach życiowych najszybciej „odbudowywana” zostaje wola życia, a dobrostan subiektywny dopiero później.

Ogólny dobrostan subiektywny (rozumiany zarówno hedonistycznie, jak i eudajmonistycznie) obejmuje poczucie szczęścia, zadowolenie z życia i bilans doświadczeń afektywnych i pozostaje pod wpływem warstw sąsiednich. Wymiar obiektywny dobrostanu obejmuje poczucie sensu i znaczenia i wynika z poznawczej oceny doświadczeń, zależącej m.in. od celów, wartości i wiedzy. Relacje między tymi wymiarami przedstawione są na rysunku 3. 


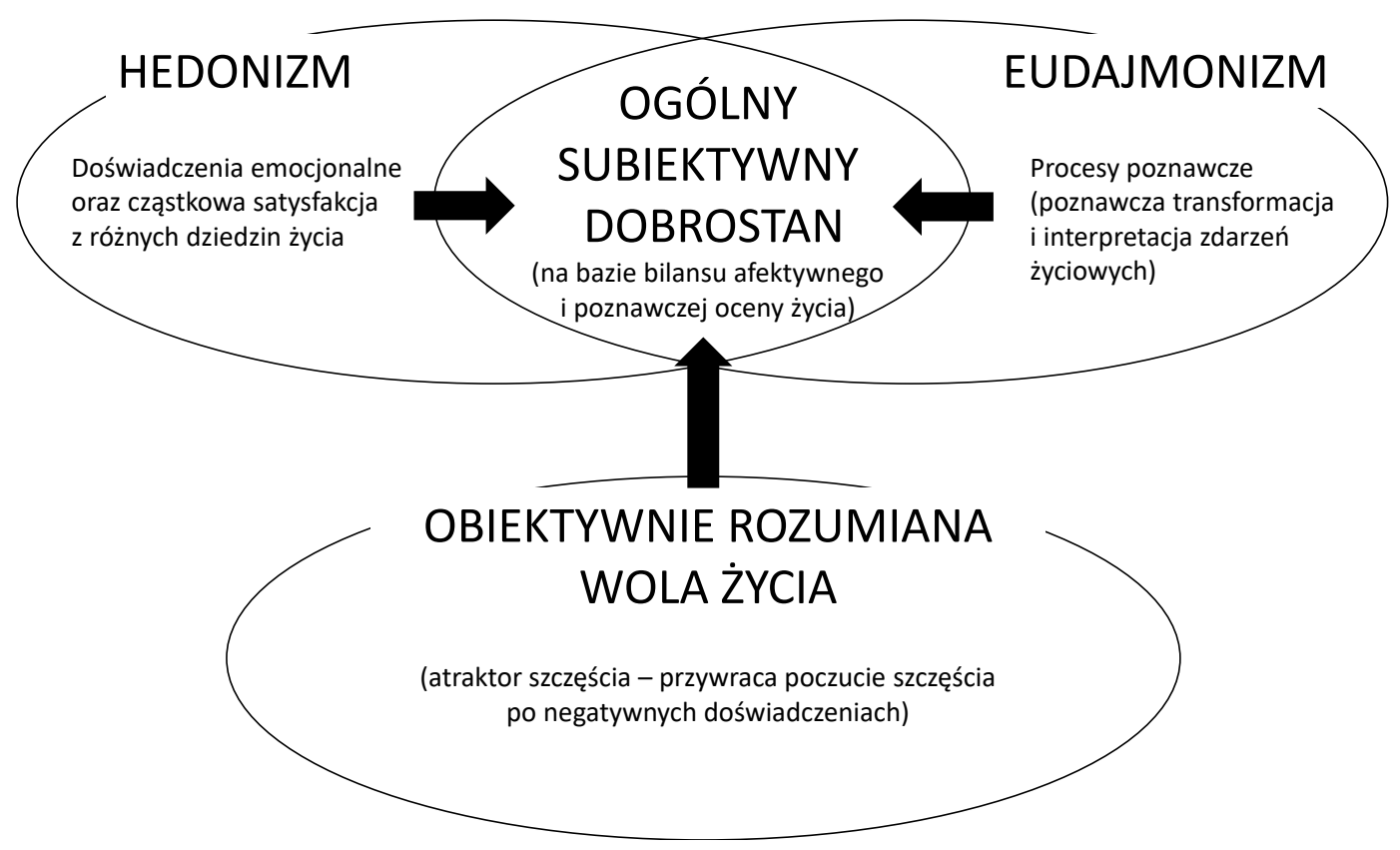

Rysunek 3. Cebulowa teoria szczęścia (opracowanie własne na podstawie: Czapiński, 2004).

\section{KONCEPCJA DOBROSTANU SUBIEKTYWNEGO DIENERA}

Jest to jedna z najpopularniejszych obecnie koncepcji dobrostanu. Diener (2000) uważa, że psychologia pozytywna jest nauką o szczęściu. Jest on autorem jednej z pierwszych koncepcji dobrostanu subiektywnego, zaliczanych do nurtu hedonistycznego. Diener zwraca uwagę, że obiektywne warunki życia nie są połączone silnie $\mathrm{z}$ subiektywnym dobrostanem, i podkreśla, że choć wskaźniki ekonomiczne i społeczne wzrosły w ciągu ostatnich lat, to jednak nie odnotowano podobnego wzrostu zadowolenia z życia.

Zdaniem Dienera, Lucasa i Oishiego (2002) dobrostan jest poznawczą i afektywną oceną życia, która może uwzględniać emocjonalne reakcje na wydarzenia, jak również poznawczą ocenę własnej satysfakcji z życia i poczucia spełnienia. Na dobrostan subiektywny składają się składniki afektywne (doświadczanie pozytywnych emocji, niska częstotliwość doświadczania emocji negatywnych) oraz składniki poznawcze (wysokie zadowolenie z życia), co schematycznie uwidocznione jest na rysunku 4. 


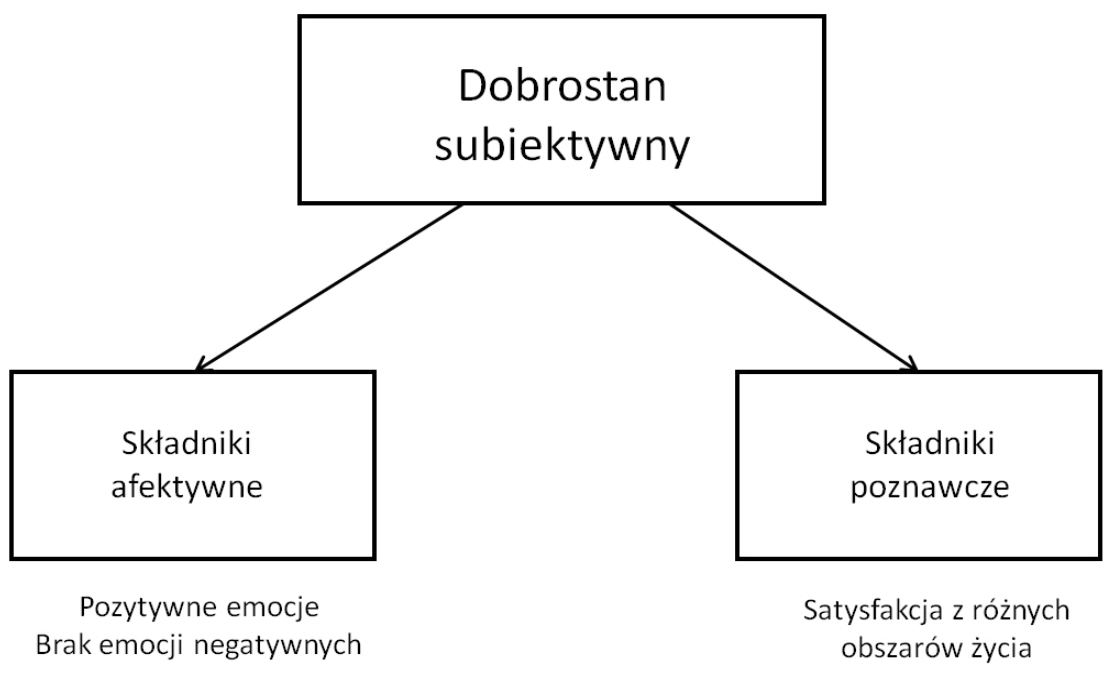

Rysunek 4. Koncepcja dobrostanu subiektywnego Dienera (zródło: opracowanie własne na podstawie: Diener, 1984).

Do pomiaru dobrostanu w rozumieniu koncepcji Dienera służy Skala zadowolenia $z \dot{z} y$ cia (Satisfaction with Life Scale; Diener i in., 1985) oraz Temporalna skala zadowolenia z życia (The Temporal Satisfaction with Life Scale; Pavot, Diener, Suh, 1998).

\section{KONCEPCJA DOBROSTANU PSYCHOLOGICZNEGO RYFF}

Koncepcja ta zalicza się do teorii eudajmonistycznych. Ryff (1989) podkreśla, że wcześniejsze koncepcje koncentrują się w zasadzie wyłącznie na stanach afektywnych i zadowoleniu z życia. Kwestionuje również zasadność tłumaczenia greckiego pojęcia eudajmonii jako szczęście i zwraca uwagę, że eudajmonia nie jest tylko subiektywnym zadowoleniem z życia, lecz uczuciem towarzyszącym realizacji ludzkiego potencjału.

Nawiązując do koncepcji Junga, Allporta, Rogersa i Maslowa oraz uwzględniając definicje zdrowia psychicznego wg Jahody, Ryff (1989) zaproponowała w swojej teorii sześć wymiarów dobrostanu (których definicje znajdują się w tabeli 3): 1) samoakceptację (self-acceptance), 2) rozwój osobisty (personal growth), 3) cel życiowy (purpose in life), 4) autonomię (autonomy), 5) panowanie nad otoczeniem (environmental mastery) i 6) pozytywne relacje $\mathrm{z}$ innymi ludźmi (positive relations with others). Do pomiaru wymiarów dobrostanu zaproponowanych przez Ryff służy Skala dobrostanu psychologicznego (Scales of Psychological Well-Being; Ryff, Keyes, 1995). 
Tabela 3. Wymiary dobrostanu psychologicznego (źródło: opracowanie własne na podstawie: Ryff, 1989)

\begin{tabular}{ll}
\hline \multicolumn{1}{c}{ Wymiar dobrostanu } & \multicolumn{1}{c}{ Definicja } \\
\hline Samoakceptacja & Pozytywny stosunek do samego siebie, akceptacja swoich wad i zalet. \\
\hline Pozytywne relacje z innymi & $\begin{array}{l}\text { Doświadczanie ciepłych i pełnych zaufania relacji interpersonalnych i kontaktów społecznych, } \\
\text { zdolność do miłości, przyjaźni, intymności, empatia. }\end{array}$ \\
\hline Autonomia & Niezależność, nieuleganie naciskom zewnętrznym, ocena siebie wg wewnętrznych standardów. \\
\hline Panowanie nad otoczeniem & $\begin{array}{l}\text { Poczucie sprawstwa, kompetencji, zdolność do przekształcania otoczenia zgodnie ze swoimi potrze- } \\
\text { bami i wartościami, radzenie sobie ze złożonymi warunkami środowiskowymi. }\end{array}$ \\
\hline Cel życiowy & $\begin{array}{l}\text { Przekonanie o ukierunkowaniu własnego życia na realizację ważnego celu, zdolność do podejmowa- } \\
\text { nia się i realizowania zadań życiowych, posiadanie wierzeń, poglądów i przekonań nadających życiu } \\
\text { cel i sens. }\end{array}$ \\
\hline Osobisty rozwój & $\begin{array}{l}\text { Umiejętność doskonalenia swoich umiejętności, realizacji swojego potencjału, poszukiwanie dróg } \\
\text { dalszego rozwoju, poczucie, że podejmowane wyzwania prowadzą do wzrostu kompetencji, samore- } \\
\text { alizacja, otwartość na doświadczenia. }\end{array}$ \\
\hline
\end{tabular}

Warto również zwrócić tutaj uwagę na używane w tym artykule sformułowanie dobrostan psychologiczny. Jest ono dokładnym odpowiednikiem używanego przez Ryff terminu psychological well-being, choć w języku polskim może nie być jednoznaczne. Pozwala ono jednak uniknąć w tłumaczeniu wyrażenia dobrostan psychiczny, które bywa w literaturze polskiej stosowane wymiennie ze słowem dobrostan, jako odpowiednikiem angielskiego well -being (por. Czapiński, 1994; Trzebińska, 2008; Wojciechowska, 2005).

Wydaje się, że pojęcie dobrostanu, choć jeszcze jakiś czas temu nie należało do języka psychologii, zostało już dość mocno ugruntowane, dlatego też warto zrezygnować z dołączania do niego określenia psychiczny (warto zauważyć jednocześnie, że dobrostan „niepsychiczny” to raczej obiektywna jakość życia).

Na wyrażenie dobrostanu w duchu koncepcji Ryff używa się również określenia dobrostan osobowościowy (Wojciechowska, 2005, 2011), w niniejszej publikacji jednak przyjęto tłumaczenie najwierniejsze oryginalnej wersji i nierodzące skojarzeń $z$ konstruktem, jakim jest osobowość.

\section{TRÓJWYMIAROWA KONCEPCJA DOBROSTANU KEYESA I WATERMAN}

Teoria ta nazywana jest przez autorów teorią dobrostanu subiektywnego i łączy ujęcia hedonistyczne i eudajmonistyczne. Keyes i Waterman (2003) rozumieją dobrostan jako zjawisko wielowymiarowe, obejmujące co najmniej trzy aspekty: 1 ) dobrostan psychologiczny ( $p s y$ chological well-being), 2) dobrostan emocjonalny (emotional well-being) oraz 3) dobrostan społeczny (social well-being). Jest to teoria operacjonalizująca zdrowie psychiczne (mental health) jako zespól symptomów dobrostanu subiektywnego (Keyes, Lopez, 2002). Autorzy zauważają, że w dotychczasowych badaniach analizowane były wyłącznie poszczególne symptomy zdrowia psychicznego, nie było zaś ujęć łączących komponenty emocjonalne, psychologiczne i społeczne. Keyes (2002) zwraca również uwagę, że zdrowie psychiczne i choroba psychiczna nie są przeciwnymi krańcami pojedynczego kontinuum, a miary symptomów choroby psychicznej korelują nisko z miarami dobrostanu subiektywnego. Keyes i Lopez (2002) są zdania, że kompletne zdrowie psychiczne, zwane przez nich rozkwitem (flourishing), obejmuje nie tylko brak psychopatologii, ale również wysoki dobrostan, a żeby w pełni zobrazować zależności między dobrostanem a psychopatologią, potrzebny jest model uwzględniający oba kontinua (rysunek 5). 


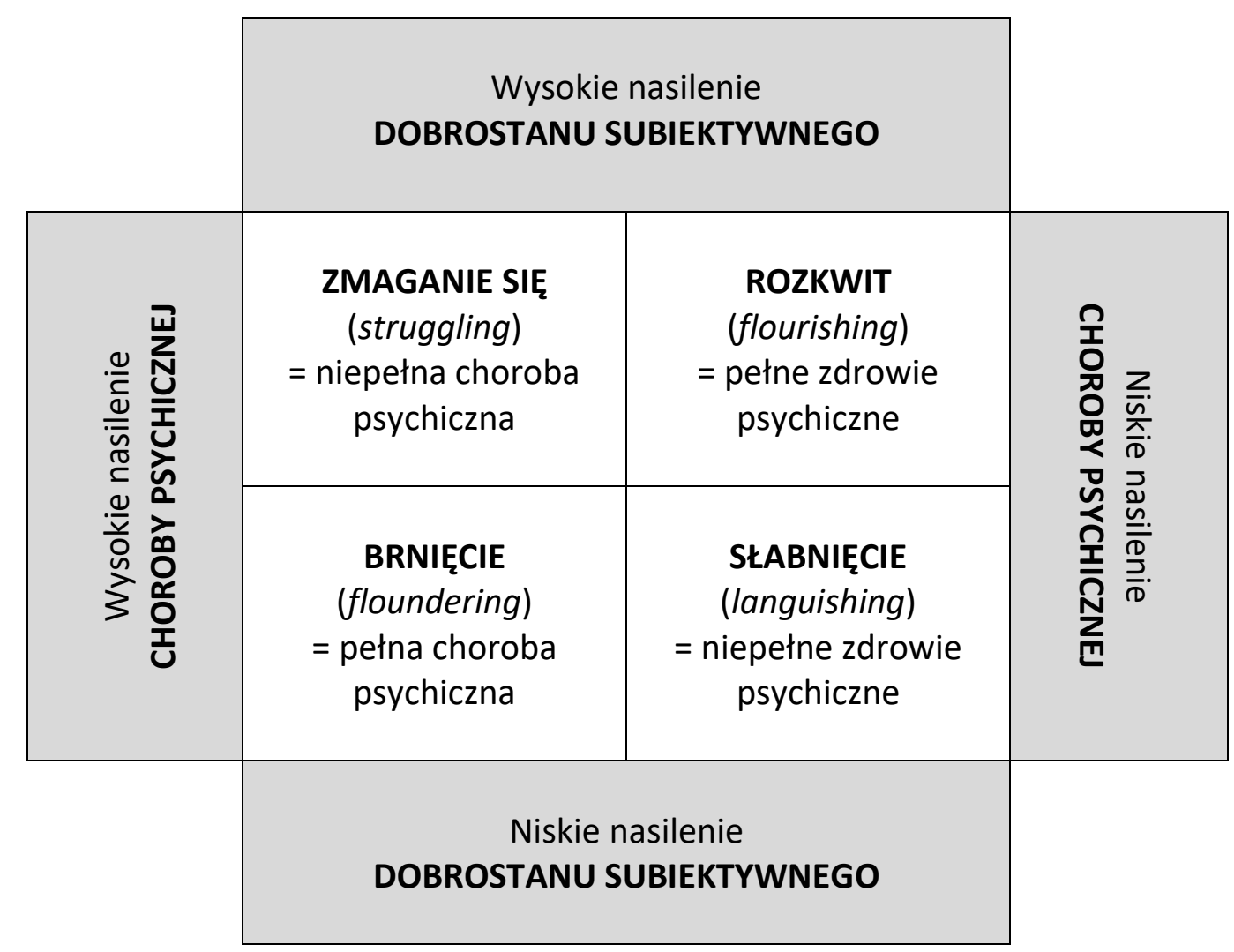

Rysunek 5. Model zdrowia i choroby psychicznej (opracowanie własne na podstawie: Keyes, Lopez, 2002).

Dobrostan subiektywny to percepcja i ocena własnego życia oparte na ocenie własnych stanów afektywnych, funkcjonowania psychicznego i społecznego (Moore, Keyes, 2003).

Dobrostan emocjonalny w tej koncepcji wywodzi się z ujęć Bradburna (1969) i Cantrila (1965) i wiąże się z doświadczaniem pozytywnych uczuć i emocji (takich jak szczęście, zainteresowanie życiem czy zadowolenie $\mathrm{z}$ życia). Dobrostan to jednak zdaniem Keyesa (2002) coś więcej niż pozytywne stany emocjonalne - to również pozytywne funkcjonowanie w sferze psychologicznej i społecznej. Dobrostan psychologiczny w tej teorii obejmuje wymienione powyżej wymiary dobrostanu psychologicznego wyróżnione przez Ryff (1989).

Dobrostan społeczny wywodzi się z koncepcji Keyesa (1998), który zauważył, że we wcześniejszych teoriach dobrostanu pomijany był kontekst społeczny, w którym znajduje się każdy człowiek, i podkreślił, że radzenie sobie z wyzwaniami i wymaganiami społecznymi może prowadzić nas do dobrostanu. Elementy dobrostanu społecznego wyróżnione przez Keyesa (2002; nazywane też spotecznymi wyzwaniami - social challenges) to: społeczna akceptacja (social acceptance), społeczna aktualizacja (social actualization), społeczna koherencja (social coherence), społeczna integracja (social integration) oraz wkład społeczny (social contribution). Zestawienie składników dobrostanu wyróżnionych w tej teorii przedstawia tabela 4. 
Tabela 4. Komponenty dobrostanu subiektywnego wg Keyesa i Waterman (opracowanie własne na podstawie: Keyes, Waterman, 2003)

\begin{tabular}{lll}
\hline \multicolumn{1}{c}{ Pozytywne odczucia } & \multicolumn{1}{c}{ Pozytywne funkcjonowanie } \\
\hline \multicolumn{1}{c}{ Dobrostan emocjonalny } & \multicolumn{1}{c}{ Dobrostan psychologiczny } & \multicolumn{1}{c}{ Dobrostan społeczny } \\
\hline $\begin{array}{l}\text { doświadczanie pozytywnych emocji } \\
\text { (szczęście, zainteresowanie, zadowolenie }\end{array}$ & samoakceptacja, pozytywne relacje & społeczna akceptacja, aktualizacja, kohe- \\
$\begin{array}{l}\text { z życia), ich przewaga nad emocjami } \\
\text { negatywnymi) }\end{array}$ & otoczeniem, cel życiowy, osobisty rozwój & rencja, integracja i wkład \\
\hline
\end{tabular}

Do pomiaru wyróżnionych wymiarów dobrostanu subiektywnego, a tym samym - zdrowia psychicznego służy Kwestionariusz zdrowia psychicznego (Mental Health Continuum; Keyes, 2002).

\section{TEORIA DOBROSTANU SELIGMANA}

Seligman (2011a) - w myśl głównych założeń psychologii pozytywnej - podkreśla, że dobrostan to coś więcej niż nieobecność stanów negatywnych. Proponuje on model, w którym dobrostan (well-being) stanowi operacjonalizację rozkwitu człowieka (flourishing) i wyróżnia pięć jego wymiarów: 1) pozytywne emocje (positive emotion), 2) osiągnięcia (achievement/accomplishment), 3) poczucie celu i sensu (meaning and purpose), 4) relacje $\mathrm{z}$ innymi ludźmi (relationships with others) i 5) zaangażowanie (engagement). Seligman podkreśla, że każdy $\mathrm{z}$ tych elementów może być mierzony niezależnie od pozostałych, każdy przyczynia się do dobrostanu, a dążenie do jednego $\mathrm{z}$ wymiarów nie jest podyktowane chęcią osiągnięcia innego. Rewiduje on tym samym swoją wcześniejszą teorię autentycznego szczęścia (authentic happiness; Seligman, 2002b), stawiając dobrostan, a nie szczęście w centrum zainteresowania psychologii pozytywnej (i podkreślając, że miarą szczęścia jest jedynie zadowolenie z życia). Seligman podkreśla jednocześnie, że niektóre z wyróżnionych przez niego elementów dobrostanu mogą być mierzone za pomocą subiektywnego samoopisu, a inne - za pomocą wskaźników obiektywnych. Najważniejsze różnice między teorią szczęścia a teorią dobrostanu pokazane zostały w tabeli 2 .

\section{TEORIA DOBROSTANU EUDAJMONISTYCZNEGO WATERMANA I IN.}

Waterman i in. (2010) operacjonalizują teorię dobrostanu eudajmonistycznego, zauważając, że jest on „efektem ubocznym” realizacji potencjału własnego człowieka. Uważają, że ich teoria jest $\mathrm{z}$ jednej strony komplementarna, a $\mathrm{z}$ drugiej - kontrastująca $\mathrm{z}$ teoriami dobrostanu subiektywnego. Zdaniem Watermana i in. w koncepcjach dobrostanu subiektywnego nie ma rozróżnienia między dobrostanem hedonistycznym a eudajmonistycznym.

Dobrostan eudajmonistyczny wiąże się z rozwojem potencjału człowieka, poczuciem celu i sensu w życiu, z życiem zgodnym z ludzką naturą. Obejmuje on zarówno komponenty subiektywne (dotyczące uczuć i emocji, których doświadcza jednostka, gdy realizuje swój potencjał), jak i obiektywne (związane $z$ jej zachowaniami). Wymiary dobrostanu eudajmonistycznego wyróżnione przez Watermana i in. (2010) to: 1) dążenie do samopoznania (self-discovery), 2) postrzegana realizacja własnego potencjału (perceived development of one's best potentials), 3) poczucie celu i sensu życia (sense of purpose and meaning in life), 4) zaangażowanie $\mathrm{w}$ działanie (intense involvement in activities), 5) inwestowanie znaczaccego wysiłku (investment of significant effort) oraz 6) zadowolenie $\mathrm{z}$ wyrażania siebie $\mathrm{w}$ działaniu (enjoyment of activities as personally expressive). 
Według Watermana i in. (2010) pytanie o relacje między poszczególnymi formami dobrostanu: dobrostanu subiektywnego (którego formą jest omawiany tutaj dobrostan spoleczny), dobrostanu psychologicznego i dobrostanu eudajmonistycznego jest nadal otwarte i wciąż brak jednoznacznego rozstrzygnięcia kwestii, czy stanowią one trzy różne zjawiska czy jedynie różne aspekty tego samego konstruktu.

Do pomiaru dobrostanu eudajmonistycznego w rozumieniu przedstawionej powyżej koncepcji służy Kwestionariusz dobrostanu eudajmonistycznego (Eudaimonic Well-Being Questionnaire; Waterman i in., 2010).

\section{PODSUMOWANIE}

Jak pokazano powyżej, istnieje wiele współczesnych koncepcji dobrostanu i wiele narzędzi, po które równie chętnie sięgają rozmaici badacze. Wydaje się, że nie ma jednej dominującej i właściwej koncepcji dobrostanu, ponieważ jest to zjawisko wielowymiarowe, a mówiąc o dobrostanie, można odnieść się do skrajnie różnych podłoży teoretycznych (jak tradycja hedonistyczna i eudajmonistyczna). Przedstawione klasyfikacje nie są rozłączne, różne nurty teoretyczne wzajemnie się przenikają oraz kładą akcent na różne aspekty dobrostanu.

Oczywiście przytoczony przegląd koncepcji dobrostanu nie jest wyczerpujący (na ten temat powstają opracowania po wielokroć przekraczające objętością niniejszy artykuł), jednak można mieć nadzieję, że porządkuje on główne nurty oraz sposoby rozumienia dobrostanu obecne we współczesnej literaturze.

\section{BIBLIOGRAFIA}

Bradburn, N. M. (1969). The structure of psychological well-being. Chicago: Aldine.

Cantril, H. (1965). The pattern of human concerns. New Brunswick: Rutgers University Press.

Compton, W. C., Hoffman, E. (2013). Positive psychology: the science of happiness and flourishing (wyd. 2). Belmont: Wadsworth.

Czapiński, J. (1994). Psychologia szczęścia. Przegląd badań i zarys teorii cebulowej. Warszawa: Pracownia Testów Psychologicznych PTP.

Czapiński, J. (2004). Spotkanie dwóch tradycji: hedonizmu i eudajmonizmu. W: J. Czapiński (red.), Psychologia pozytywna. Nauka o szczęściu, zdrowiu, sile i cnotach człowieka (s. 13-17). Warszawa: PWN.

Czerw, A. (2011). Psychologia pozytywna i jej rozwój w Polsce. Psychologia Jakości Życia, 10(1), 1-6.

Diener, E. (1984). Subjective well-being. Psychological Bulletin, 95, 542-575. https://doi.org/10.1037/0033-2909.95.3.542

Diener, E. (2000). Subjective well-being. The science of happiness and a proposal for a national index. American Psychologist, 1, 34-43. https:// doi.org/10.1037/0003-066X.55.1.34

Diener, E., Emmons, R. A., Larsen, R. J., Griffin, S. (1985). The Satisfaction with Life Scale. Journal of Personality Assessment, 49, 71-75. https://doi. org/10.1207/s15327752jpa4901_13

Diener, E., Lucas, R. E., Oishi, S. (2002). Subjective well-being. The science of happiness and life satisfaction. W: C. R. Snyder, S. J. Lopez (red.), Handbook of positive psychology (s. 63-73). Nowy Jork: Oxford University Press.

Forgeard, M. J. C., Jayawickreme, E., Kern, M., Seligman, M. E. P. (2011). Doing the right thing: measuring wellbeing for public policy. International Journal of Wellbeing, 1(1), 79-106. https://doi.org/10.5502/ijw.v1i1.15

Fredrickson, B. L., Losada, M. F. (2005). Positive affect and complex dynamics of human flourishing. American Psychologist, 60, 678-686. https:// doi.org/10.1037/0003-066X.60.7.678

Gilman, R., Huebner, S., Buckman, M. (2009). Life satisfaction. W: S. J. Lopez (red.), The encyclopedia of positive psychology (t. 1, s. 582-585). Chichester: Willey-Blackwell.

Greene-Shortridge, T. M., Odle-Dusseau, H. N. (2009). Quality of life. W: S. J. Lopez (red.), The encyclopedia of positive psychology (t. 2, s. 817-821) Chichester: Willey-Blackwell.

Gulla, B. Tucholska, K. (2007). Psychologia pozytywna: cele naukowo-badawcze i aplikacyjne oraz sposób ich realizacji. Studia z Psychologii w KUL, 14, 133-152.

Heszen-Niejodek, I. (1996). Jakość życia w badaniach psychologicznych. Śląskie Studia Historyczno-Teologiczne, 29, $251-255$. 
Jahoda, M. (1958). Joint commission on mental health and illness monograph series: T. 1. Current concepts of positive mental health. Nowy Jork: Basic Books.

Kaczmarek, Ł. D. (2016). Pozytywne interwencje psychologiczne. Dobrostan a zachowania intencjonalne. Poznań: Zysk i S-ka.

Kossakowska, M. (2014). Positive psychology in Poland - Introduction. Polish Psychological Bulletin, 45, 101-102. https://doi.org/10.2478/ppb2014-0014

Kahneman, D. (1999). Objective happiness. W: D. Kahneman, E. Diener, N. Schwarz (red.), Well-being: the foundations of hedonic psychology (s. 3-25). Nowy Jork: Russell Sage Foundation.

Keyes, C. L. M. (1998). Social well-being. Social Psychology Quarterly, 61, 121-140. https://doi.org/10.2307/2787065

Keyes, C. L. M. (2002). The mental health continuum: from languishing to flourishing in life. Journal of Health and Social Behavior, 43, 207-222. https://doi.org/10.2307/3090197

Keyes, C. L. M., Lopez, S. J. (2002). Toward a science of mental health: Positive directions in diagnosis and interventions. W: C. R. Snyder, S. J. Lopez (red.), Handbook of positive psychology (wyd. 2, s. 45-59). Nowy Jork: Oxford University Press.

Keyes, C. L. M., Waterman, M., B. (2003). Dimensions of well-being and mental health in adulthood. W: M. H. Bornstein, L. Davidson, C. L. M. Keyes, K. A. Moore (red.), The Crosscurrents in Contemporary Psychology Series: Well-being. Positive development across the life course (s. 477-497). Mahwah: Erlbaum.

Lopez, S. J., Snyder, C. R. (2011). The Oxford handbook of positive psychology (wyd. 2). Nowy Jork: Oxford University Press.

Maddux, J. E. (2002). Stopping the "madness". Positive psychology and the deconstruction of the illness ideology and the DSM. W: C. R. Snyder, S. J. Lopez (red.), Handbook of positive psychology (s. 13-25). Nowy Jork: Oxford University Press.

McMahan, E. A., Estes, D. (2011). Hedonic versus eudaimonic conceptions of well-being: Evidence of differential associations with experienced well-being. Social Indicators Research, 103, 93-108. https://doi.org/10.1007/s11205-010-9698-0

Moore, K. A., Keyes, C. L. M. (2003). A brief history of well-being in children and adults. W: M. Bornstein, L. Davidson, C. L. M. Keyes, K. A. Moore (red.), Well being: positive development across the life course (s. 1-11). Londyn: Lawrence Erlbaum Associates.

Pavot, W., Diener, E., Suh, E. (1998). The Temporal Satisfaction With Life Scale. Journal of Personality Assessment, 70, 340-354. https://doi. org/10.1207/s15327752jpa7002_11

Ryan, R. M., Deci, E. L. (2001). On happiness and human potentials: a review of research on hedonic and eudaimonic well-being. Annual Review of Psychology, 52, 141-166. https://doi.org/10.1146/annurev.psych.52.1.141

Ryff, C. D. (1989). Happiness is everything, or is it? Explorations on the meaning of psychological well-being. Journal of Personality and Social Psychology, 57, 1069-1081. https://doi.org/10.1037/0022-3514.57.6.1069

Ryff, C. D., Keyes, C. L. (1995). The structure of psychological well-being revisited. Journal of Personality and Social Psychology, 69, 719-727. https://doi.org/10.1037/0022-3514.69.4.719

Ryff, C. D., Singer, B. (1998). The contours of positive human health. Psychological Inquiry, 9, 1-28. https://doi.org/10.1207/s15327965pli0901_1

Ryff, C. D., Singer, B. (2002). From social structure to biology: integrative science in pursuit of human health and well-being. W: C. R. Snyder, S. J. Lopez (red.), Handbook of positive psychology (s. 541-554). Nowy Jork: Oxford University Press.

Schueller, S. M., Seligman, M. E. P. (2010). Pursuit of pleasure, engagement, and meaning: relationships to subjective and objective measures of well-being. Journal of Positive Psychology, 5, 253-263. https://doi.org/10.1080/17439761003794130

Schwarz, N., Strack, F. (1999). Reports of subjective well-being: judgmental processes and their methodological implications. W: D. Kahneman, E. Diener, N. Schwarz (red.), Well-being - the foundation of hedonic psychology (s. 61-84). Nowy Jork: Russell Sage Foundation.

Seligman, M. E. P. (2002a). Positive psychology, positive prevention, and positive therapy. W: C. R. Snyder, S. J. Lopez (red.), Handbook of positive psychology (s. 3-9). Nowy Jork: Oxford University Press.

Seligman, M. E. P. (2002b). Authentic happiness. Nowy Jork: Free Press.

Seligman, M. E. P. (2011a). Flourish: a visionary new understanding of happiness and well-being [Kindle DX version]. Pobrane z: https://www. amazon.com/Flourish-Visionary-Understanding-Happiness-Well-being-ebook/dp/B0043RSK90

Seligman, M. E. P. (2011b). Pełnia życia. Nowe spojrzenie na kwestię szczęścia i dobrego życia. Poznań: Media Rodzina.

Tatarkiewicz, W. (1985). O szczęściu. Warszawa: PWN.

Trzebińska, E. (2008). Psychologia pozytywna. Warszawa:Wydawnictwa Akademickie i Profesjonalne.

Waterman, A. (1993). Two conceptions of happiness: contrasts of personal expressiveness (eudaimonia) and hedonic enjoyment. Journal of Personality and Social Psychology 64, 678-691. https://doi.org/10.1037/0022-3514.64.4.678

Waterman, A. S., Schwartz, S. J., Zamboanga, B. L., Ravert, R. D., Williams, M. K., Agocha, V. B, ... Donnellan, M. B. (2010). The questionnaire for eudaimonic well-being: psychometric properties, demographic comparisons, and evidence of validity. The Journal of Positive Psychology, 5 , 41-61. https://doi.org/10.1080/17439760903435208

Wojciechowska, L. (2005). Teoria dobrostanu w badaniach rozwojowych nad rodziną: dobrostan rodziców w stadium pustego gniazda. Psychologia Rozwojowa, 10(4), 35-45.

Wojciechowska, L. (2011). Dobrostan psychiczny adolescenta w obliczu realizacji rozwojowych zadań społecznych. W: D. Borecka-Biernat (red.), Zaburzenia w zachowaniu dzieci i młodzieży w kontekście trudnych sytuacji szkolnych i pozaszkolnych (s. 13-40). Kraków: Impuls. 
World Health Organization (1948). Constitution of the World Health Organization. Pobrane z: http://www.who.int/governance/eb/who_constitution_en.pdf

Zawadzka, A. M., Szabowska-Walaszczyk, A. (2014). Does self-improvement explain well-being in life at workplace? Analysis based on selected measures of well-being. Polish Psychological Bulletin, 45, 134-141. https://doi.org/10.2478/ppb-2014-0018 